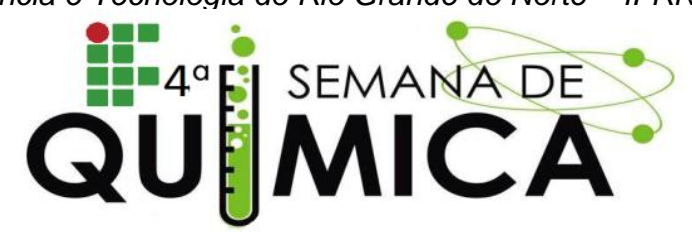

\title{
UTILIZANDO A EXPERIMENTAÇÃO COMO ESTRATÉGIA DIDÁTICA PARA O ENSINO DE QUÍMICA
}

${ }^{1}$ FERREIRA, W. S. S. (IFRN); ${ }^{1}$ JALES, A. A. (IFRN); ${ }^{1}$ MACÊDO, V. S. (UERN); ${ }^{2}$ MENEZES, M. L. S. (IFRN).

Palavras Chave: Ensino de Química, teoria e prática, estratégia didática.

\section{INTRODUÇÃO}

Sabendo-se que, alguns conteúdos de Química não são fáceis de serem assimilados pelos alunos somente com a teoria, optou-se por ministrar uma aula utilizando a estratégia didática de relacionar a teoria com a prática, em uma aula sobre "preparo de soluções". Segundo Paulo Freire (1996), aprender e educar são processos que envolvem a transmissão, a fixação e a produção de saberes, memórias, sentidos e significados, práticas e performances. É nesse sentido que o uso de atividades experimentais facilita significativamente a aprendizagem do aluno, pois como vemos no triângulo da Química, os alunos precisam ter respaldo em três noções básicas: submicroscópico, macroscópio e simbólico.

METODOLOGIA

A pesquisa foi realizada com 14 alunos da $2^{\text {a }}$ série $B$, turno matutino, logo após uma aula sobre "preparo de soluções", ministrada por duas bolsistas do PIBID, no Laboratório de Ciências da Escola Estadual Juscelino Kubitschek, localizada na cidade de Assú/RN. A maioria dos educandos gastou em média 15 minutos para responder o questionário. As questões pesquisadas foram as seguintes:

19 A teoria relacionada com a prática facilitou seu aprendizado? Explique.

20 Quais as dificuldades encontradas para manusear o experimento realizado?

RESULTADOS E DISCUSSÕES

Analisando as respostas da 1 a questão de pesquisa, pôde-se constatar que, $100 \%$ da turma, ou seja, os 14 discentes presentes na aula conseguiram compreender melhor a teoria a partir da experimentação realizada. Portanto, a estratégia didática de relacionar a teoria com a prática contribui sim para no processo de ensino-aprendizagem. A seguir, algumas respostas dos educandos:

- Sim, a teoria explica bastante coisa, mas a prática esclarece as dúvidas.

- Sim, porque com a prática é mais fácil de raciocinar e aprender.

- Sim, a prática facilitou muito o aprendizado. É muito melhor na prática do que somente a teoria.

Com relação à $2^{a}$ questão, a maioria dos alunos relatou que, a maior dificuldade deles foi com os cálculos necessários para realizar a prática. O gráfico abaixo mostra a porcentagem das respostas dos alunos:

\section{Questão 2}

- Com os cálculos —Coma balança nenhuma

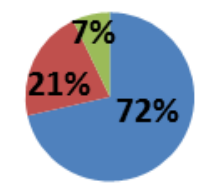

Gráfico 1 - Porcentagem das respostas da 2a questão de pesquisa. Fonte: JALES, 2016.

CONCLUSÃO

Diante dos resultados obtidos pôde-se constatar que, quando a teoria é relacionada com a prática, os educandos aprendem mais facilmente e que a maior dificuldade que eles tiveram foi com os cálculos.

REFERÊNCIAS

Freire, Paulo. Pedagogia da autonomia: saberes necessários à prática educativa/ Paulo FreireSão Paulo: Paz e Terra, 1996 (Coleção Leitura). Reimpresso, 2010. 